Article

\title{
Effect of the Disclosure of Corporate Social Responsibility on Business Profitability. A Dimensional Analysis in the Spanish Stock Market
}

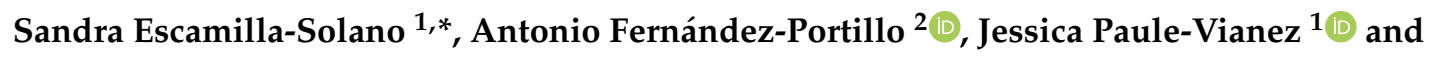 \\ Paola Plaza-Casado ${ }^{1}$ \\ 1 Department of Business Economics, Rey Juan Carlos University, Paseo Artilleros s/n, 28032 Madrid, Spain; \\ jessica.paule@urjc.es (J.P.-V.); paola.plaza@urjc.es (P.P.-C.) \\ 2 Department of Financial Economics and Accounting, University of Extremadura, Av. De la Universidad s/n, \\ 10003 Cáceres, Spain; antoniofp@unex.es \\ * Correspondence: sandra.escamilla@urjc.es; Tel.: +34-9148-884-039
}

Received: 31 October 2019; Accepted: 25 November 2019; Published: 27 November 2019

\begin{abstract}
In recent decades, the novel fact of considering corporate social responsibility (CSR) as part of the corporate strategy of companies has resulted in interest groups demanding the disclosure of such information. Likewise, considering their importance of transparency and governance today, it is necessary to make an approximation on the study of the divulgation of CSR information on companies listed on the Spanish stock market. The aim of this work is to determine whether the disclosure of the measures taken by the companies on CSR influences business profitability. Applying PLS-SEM on the information extracted from the sustainability reports of 103 companies listed on the Spanish continuous market, it is found that the disclosure of CSR measures improves business profitability in its social and economic dimensions, with no effect being found between the disclosure CSR in its environmental dimension on business profitability.
\end{abstract}

Keywords: corporate social responsibility; business profitability; PLS

\section{Introduction}

Over the years, people and businesses have become increasingly aware of environmental and social problems. In this way, corporate awareness implies being economically, socially, and environmentally sustainable [1].

According to a KPMG study, more than $90 \%$ of the world's largest companies applied corporate social responsibility (CSR) in the last eight years, in 2017 more than $60 \%$ of all companies in each industry sector [2]. Consequently, a large number of studies have focused on the mechanisms through which the implementation of CSR measures leads to better business results.

The influence of the implementation of CSR on business results is a line of inconclusive research [3]. This is an issue that has received special attention since the 1970s with the contributions of [4] and [5] and that continues today, not yet reaching a consensus on how they influence the CSR measures taken in the profitability of companies.

One of the most common motivations for which no CSR measures are applied, derives in that many entrepreneurs and directors determinate that they cannot afford to spend money on these activities, since they will affect the profitability of their companies [1]. In fact, they should be considered an investment and not an expense [6] since in the long term the implementation of CSR measures is a source of competitive advantage [7].

Under Spanish law, listed companies are required to disclose their economic and financial information. The scandals experienced in recent years in terms of transparency and governance, 
and the demand by society that companies be more sustainable, efficient, and transparent in their management, have resulted in the European Union approving Directive 95/2014/EU in regards to disclosure of non-financial and diversity information by certain large undertakings and groups with the intention of regulating the information that companies disclose about the CSR actions they carry out. The application of this directive has opened a debate on whether or not companies comply with it and what is the objective pursued of the said compliance [8,9]. Moreover, numerous investigations have indicated the importance for companies to disseminate CSR information not only since compliance with the said directive but as a sign of a commitment to society [10-12], converting the dissemination of information on CSR in a competitive advantage [6]. Likewise, it necessary to clarify that, although the directive is from 2014, it is not until Royal Decree-Law 11/2018, of 28 December, when it is included in the Spanish legislation by the Spanish government.

Therefore, the objective of this work is to determine whether the divulgation of the measures taken by companies on CSR influence business profitability. The sample used will be the 103 companies listed on the Spanish continuous market that have their economic-financial information available in the SABI database. The information related to the dissemination of CSR has been extracted through an analysis of the content of the sustainability reports.

This paper presents a series of contributions in different areas, first clarifying the existing literature when analyzing the impact of each dimension of CSR on business profitability, finding that most studies take CSR in general terms, focus on a single of its dimensions, or use a single indicator. Second, in order to be able to generalize the results obtained, both profitability on own resources, profitability on capital employed, and profitability on total assets are taken, as well as the profit margin. Third, based on the methodology used, being partial least squares structural equation modeling (PLS-SEM) one of the most promising methodologies to determine different causal relationships. Finally, another great contribution made by this work lies in the fact that Spanish companies have been analyzed, finding that most of the existing studies are applied to British companies and Americans.

From here, the work is structured as follows.

In Section 2, a review of the literature on CSR will be carried out and the topic to be discussed in the study will be raised. Section 3 will inform you of the data used. Section 4 will explain the selected methodology. The results obtained will be presented in Section 5. Finally, in Section 6 the discussion and conclusions will be developed.

\section{Literature Review}

In studying CSR, the existence of numerous definitions and theories is noted, which leads us to a great lack of consensus $[13,14]$. The CSR focuses on "the voluntary integration by the company, both in its form of government and management, of social, environmental, economic and respect for human rights arising from the company's relations with its direct interest groups, as well as with any person who is affected by the development of its economic activity" [15] (p. 428). The company must assume a responsibility that goes beyond what is legally required [16] and improve the social and economic well-being of the company, as well as the surrounding environment $[16,17]$.

Throughout the 20th century, several studies [18-28] defend the union between social and economic value, and the benefits they generate. They do not conceive management in the company without the implementation of CSR policies that allow generating value to all interest groups of the company. With the positions of $[29,30]$, who consider that the only business objective is to maximize shareholder value, a wide debate was opened on whether or not to implement CSR policies in companies.

Those who really make possible evolution of the concept of CSR are the different stakeholders affected by the companies [31]. The shareholders increasingly demand transparency in the actions carried out by the company with the objective of transferring trust to the company and to the market itself. The customer's request quality and innovative products and services at fair prices every day [32]. In addition, the society is aware that for the company to succeed it cannot stay out of CSR. 
This change of philosophy is derived by the change of business paradigm. The objective of the company is no longer to maximize profit and take care of shareholders, but it complements traditional values with those demanded by stakeholders. In this context, the implementation of CSR policies is justified by the fact that it helps resolve conflicts and distribute the value created among the different groups. For this, every institution must have knowledge of the demands of society, as well as an operational operation that contributes to sustainable development $[19,20,23,33,34]$. Socially responsible behaviour has positive long-term effects since it helps to ensure the sustainability of the company and society [25]. Reinforces its competitive position by the greater acceptance of its image and, therefore, minimizes its reputational risk $[25,28,35]$. Facilitates the acquisition of competitive advantages $[7,36,37]$, and increases their legitimacy [38].

Several scholars suggest that CSR consists of multiple dimensions, each of which is represented by a group of different voluntary activities [39]. According to [20] two dimensions were established: Ethical and philanthropic responsibilities. Likewise, [40] noted that the multidimensionality could be a better assessment by a stakeholder framework (shareholders, owners, employees, suppliers, customers, and public stakeholders such as community and the natural environment).

Following [40], stakeholders have different rights and interest in a company. The company is required to implement different activities and policies that meet the diverse need of each stakeholder to achieve superior financial performance [41]. Suggested that different dimensions represent CSR to stakeholders: Social, economic, and environmental dimension [6,26,42].

Traditionally, the social dimension was associated with the philanthropic character of the donation made by companies to charitable institutions, interpreted by society as a moral obligation that it had with it. Following the European Union Green Paper, this dimension was marked by all the behaviours whose impact directed to the care of the intellectual and human capital of the company [43,44]. Those carried out by the company aimed at improving the social and economic well-being of society, as well as those aimed at "respecting the socio-cultural authenticity of the host communities and the conservation of their cultural assets" [42] (p. 150). In turn, the management of intangible assets such as reputation through CSR [45] allows being a driver of competitive advantages [46-48] and value creation as an asset that has great strategic value [49-53]. The perception that consumers have about the CSR actions carried out by the company can influence purchasing decisions [54,55].

In the economic dimension it has always been generalized that the only objective that companies must set is to maximize the benefits generated [30]. To offer a socially responsible economic dimension, with the objective to create value towards the different interest groups, various issues must be considered. The proper use of the investments made by the shareholders, as well as the requirement of greater transparency in their actions that allow transferring confidence to the company and the market itself [26]. Customers must also be valued, attending to their needs, and offering products and services with a good value for the money [32]. Suppliers are another important link in the value chain for the good progress of the company, and these require confidence and security to establish a strategy within the company [56]. For this, an optimal payment must be made for your services or products. Regarding the company, the economic activities carried out by the companies must have long-term viability and that it is correctly distributed [42], in addition to guaranteeing ethical behavior in all their actions [57] and expressing a clear commitment to respect human rights [58].

About the environmental dimension, it should be considered that all decisions taken by companies could have an impact on the environment, not only by consuming natural resources but also, through a direct impact of their activity. Therefore, the maintenance of a proactive position in environmental management will be well seen by society [59], either by measuring direct and indirect emissions [60,61], using indicators such as toxic release inventory [59,62], or calculating the carbon footprint (CDP), obtaining the ISO 14,001 certification [63], or by establishing corporate environmental strategies [64-66].

An issue that arises in CSR research is its possible effect on the profitability of the companies that carries it out. Although the fundamental objective of the company is to maximize its value for the stakeholders, it is of interest to determine if that maximization of value is at odds with the maximization 
of its profits. Along these lines, there is a debate about whether an investment in CSR harms business profitability, positive or neutral.

Regarding the studies that defend the existence of a negative relationship between investment in CSR and business profitability, these are mainly based on the fact that the expenses associated with the implementation of CSR measures are greater than the profits generated by these behaviors [1]. Among the studies that defend a negative relationship between investment in CSR and business profitability are those by [67-74].

Studies that defend a positive relationship between investment in CSR and corporate profitability argue that the coincident objectives between stakeholders and companies strengthen profitability [1] by considering CSR a source of competitive advantage [3]. Among the studies that support this relationship are those of $[3,4,14,16,42,75-94]$.

However, some studies find no relationship between investment in CSR and business profitability. Among the studies that argue that the implementation of CSR measures in companies does not influence their profitability, but in the line of [95], fulfil moral and social responsibilities, are those of [1,96-104].

Based on the lack of consensus found, this paper aims to determine the possible relationship between the disclosure of CSR and corporate profitability. One of the great contributions of this work is that it does not only analyze the influence of the implementation of CSR measures in a generic way on business profitability, but that it breaks down the CSR into its main dimensions to be able to determine individually, the impact of each dimension about profitability.

This investigation assumes that, if the stakeholders perceive an increase in the value of the company due to the disclosure of the CSR measures that it applies, that increase in value will have compensated by an increase in profits, and, therefore, of its business profitability. In this way, based on the different dimensions in which the CSR is divided, the following hypotheses will be tested in this work:

Hypotheses 1. The dissemination of CSR in its social dimension increases business profitability.

Hypotheses 2. The dissemination of CSR in its environmental dimension increases business profitability.

Hypotheses 3. The disclosure about CSR in its economic dimension increases business profitability.

\section{Data}

To test the hypotheses proposed in this study, we have taken the sample of 103 companies that are listed on the General Index of the Madrid stock exchange (IGBM) and the continuous market, and that have their economic-financial information available based on SABI data. The study period used was the year 2018.

To collect the information related to the dissemination of CSR in its different dimensions, content analysis has been carried out, expressing the items grouped into four blocks:

1. General block: To answer the most general aspects of the analysis, consisting of four items (This block has been used for data extraction, but not for empirical testing).

2. Social block: Composed of 13 items, it is analyzed what kind of social actions they carry out and what interest groups they are trying to satisfy.

3. Environmental block: Composed of nine items, includes all environmental information

4. Economic block: Composed of 11 items, collects information that can affect the well-being of companies such as transparency, brand management, etc.

In Table 1, the items are expressed throughout the content analysis, which refers to the three dimensions of the CSR. These variables follow the line of previous works on CSR and the analysis technique itself such as $[10,105,106]$. 
Table 1. Relationship of study variables.

\begin{tabular}{|c|c|}
\hline \multicolumn{2}{|c|}{ SOCIAL DIMENSION } \\
\hline SOC. 1 Assistance and social benefits & {$[107,108]$} \\
\hline SOC. 2 Sponsorship and patronage & [109] \\
\hline SOC. 3 Foundation & [15] \\
\hline SOC. 4 Reconciliation of work and family life & [107] \\
\hline SOC. 5 Employment for disabled personnel & [110] \\
\hline SOC. 6 Continuous training & {$[44,107,111]$} \\
\hline SOC. 7 Equal opportunity & European Union Green Paper, Global Compact, OIT \\
\hline SOC. 8 Respect for human rights & European Union Green Paper, Global Compact \\
\hline SOC. 9 Occupational Health and Safety & {$[107,112]$} \\
\hline SOC. 10 Corporative volunteering & {$[15,113]$} \\
\hline SOC. 11 Clients satisfaction & {$[54,55]$} \\
\hline \multicolumn{2}{|l|}{ SOC. 12 Certificate EFR } \\
\hline \multicolumn{2}{|c|}{ ENVIRONMENTAL DIMENSION } \\
\hline ENV. 1 Certificate ISO & {$[63,114-116]$} \\
\hline ENV. 2 Performance of environmental audits & [106] \\
\hline ENV. 3 Innovation projects & [15] \\
\hline ENV. 4 Waste management & {$[15,59,66]$} \\
\hline ENV. 5 Eco-efficiency programs & {$[15,59,66]$} \\
\hline ENV. 6 Programs to reduce CO2 & [117] \\
\hline ENV. 7 Included in CDP & [117] \\
\hline ENV. 8 Environmental training & [6] \\
\hline \multicolumn{2}{|c|}{ ECONOMIC DIMENSION } \\
\hline ECO. 1 Inclusion of mission, values, and CSR vision & [57] \\
\hline ECO. 2 Good brand management & {$[118,119]$} \\
\hline ECO. 3 Included in sustainable indexes & [120] \\
\hline ECO. 4 Compliance with the United Nations Global Compact & [121] \\
\hline ECO. 5 Cost reduction & [122] \\
\hline ECO. 6 Code of Ethics and Conduct & {$[108,123]$} \\
\hline ECO. 7 Relationship with suppliers & [15] \\
\hline ECO. 8 Information transparency & {$[55,115,124,125]$} \\
\hline ECO. 9 Sustainable development goals & [126] \\
\hline ECO. 10 Value creation management model & [15] \\
\hline
\end{tabular}

To collect the items grouped in the different dimensions of the CSR, the information of the reports published by the different companies in 2017 and 2018 has been used to record the CSR measures that each company has disclosed and those that have not.

Since the objective of the study is to analyze the possible influence of the dissemination of the different CSR measures of companies in their business profitability, it is relevant to determine what measures will be used to represent business profitability. To measure business profitability in the CSR literature many measures have been used. In this paper, we focus on measures related to accounting and financial data, the most used measures being financial profitability and economic profitability $[42,79,86,127-131]$. In this study, to represent such profitability the following items have been used: RENT 1_Profitability on own resources, RENT 2_Profitability on capital employed, RENT 3_Profitability on total assets, and RENT 4_Profit margin, trying to give a broader view of business profitability. These data have been extracted from the SABI database (Iberian Balance Analysis System).

\section{Methodology}

The statistical technique chosen to analyze the data described in the previous section has been PLS-SEM. This is an analysis based on the predictive capacity of the model on the final dependent variable based on the variance of the dependent variables [132]. Moreover, this type of analysis allows the construction of latent variables from indicators or manifest variables, so that a theoretical model could be represented and studied more easily [133].

For this reason, to apply this technique, first, it is necessary to be clear about how to build the model in PLS, and, from here, decide how to apply the technique properly. In this case, when analyzing the indicators that form the latent constructs or variables, it is observed that according to the 
recommendations of [134-136], there is a structural model formed by compounds of type A and type B. Where the appropriate algorithm for its correct evaluation is PLS [137,138].

Once at this point, it should be clarified that the sample size is enough for our study and the chosen technique [139-141]. Another interesting point is that only categorical indicators have been used in the independent variables, following the recommendations of [142] and that the dependent variables are measured through continuous indicators. Moreover, special care has been taken not including indicators with missing values, thus complying with the requirements of the technique [143] and obtaining more robust results. In this way, the proposed model would look like the one that can be seen below in Figure 1.

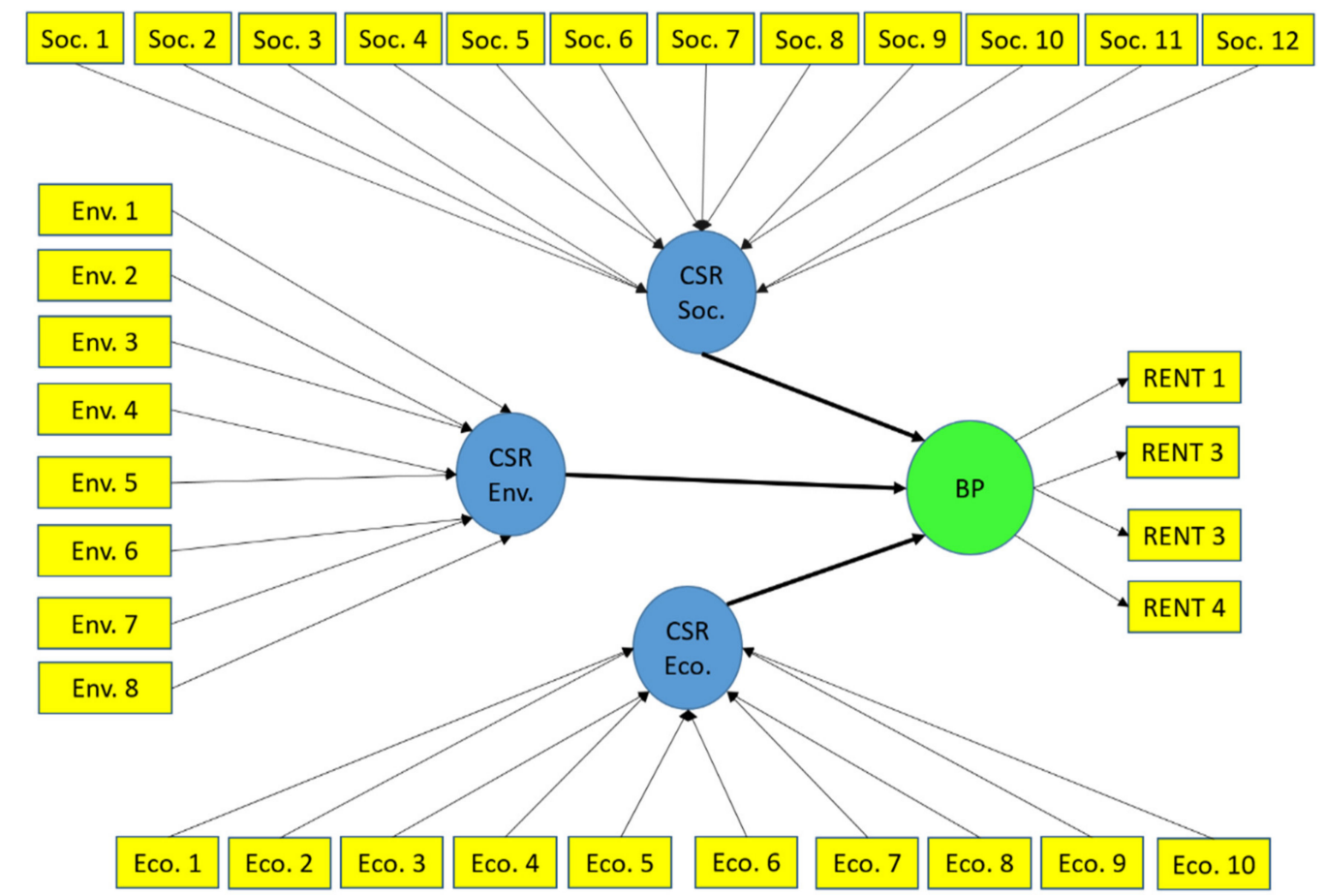

Figure 1. Initial structural model.

Regarding the application of the technique, first, the compounds in Mode A (CSR corporate profitability) will be assessed, where the individual reliability of the indicators, the reliability of the construct, the convergent validity, and the discriminant validity will be analyzed. Following the values of the indicators according to each case (see Table 2).

Table 2. Parametric values justification.

\begin{tabular}{cccc}
\hline Analysis & Parametric & Values Greater Than & Justification \\
\hline Individual reliability & Charges $(\lambda)$ & 0.4 & {$[143,144]$} \\
& Cronbach Alpha $(\alpha)$ & 0.7 & {$[145]$} \\
Reliability of construct & rho_A $(\rho \mathrm{A})$ & 0.7 & {$[146]$} \\
& Composite reliability $(\mathrm{Cr})$ & 0.6 & {$[145,147]$} \\
Convergent validity & Average extracted variance $(\mathrm{AVE})$ & 0.5 & {$[148,149]$} \\
Discriminant validity & Compare the AVE with the & AVE $>$ Correlations & {$[133,149]$} \\
\hline
\end{tabular}

Source: [150,151].

Secondly, the compounds in Mode B (CSR Social, CSR Environmental, and CSR Economic) will be attended, where multicollinearity will be analyzed and indicators with the variance inflation factor (VIF) less than 3.3 will be eliminated [152]. The relevance and significance of the weights of the 
indicators that make up each construct, and for the latter, a Bootstrapping of 10,000 iterations will be carried out, with the bootstrap percentile configuration, where indicators that do not meet the requirements set will be eliminated.

Third, the structural model will be assessed, and, for this, its collinearity, the algebraic sign, magnitude, and significance of the path coefficients, assessment of the coefficient of determination $\mathrm{R}^{2}$, and decomposition of the variance will be analyzed.

\section{Results}

For the analysis of the results, debugging of the indicators of the composite constructs in Mode A will begin, and the PLS algorithm will be executed, obtaining the results that can be observed in Tables 3-5.

Table 3. Reliability and validity of the construct.

\begin{tabular}{ccccc}
\hline & $\begin{array}{c}\text { Cronbach } \\
\text { Alpha }\end{array}$ & rho_A & $\begin{array}{c}\text { Composite } \\
\text { Reliability }\end{array}$ & $\begin{array}{c}\text { Average Extracted } \\
\text { Variance (AVE) }\end{array}$ \\
\hline CSR Economic & & 1.000 & & \\
CSR Environmental & & 1.000 & & \\
CSR Social & 0.805 & 0.922 & 0.872 & 0.643 \\
Business profitability & 0.000 & & \\
\hline
\end{tabular}

Table 4. Discriminant validity by Fornell-Larcker.

\begin{tabular}{ccccc}
\hline & CSR Economic & $\begin{array}{c}\text { CSR } \\
\text { Environmental }\end{array}$ & CSR Social & $\begin{array}{c}\text { Business } \\
\text { Profitability }\end{array}$ \\
\hline Fornell-Larcker & & \\
\hline CSR Economic & & & \\
CSR Environmental & 0.533 & & & \\
CSR Social & 0.317 & 0.543 & & \\
Business profitability & 0.366 & 0.242 & 0.346 & 0.802 \\
& Cross loads & & & \\
\hline Profit margin & 0.167 & 0.062 & 0.041 & 0.471 \\
Profitability on capital employed & 0.326 & 0.217 & 0.369 & 0.926 \\
Profitability on total assets & 0.369 & 0.261 & 0.363 & 0.949 \\
Profitability on own resources & 0.269 & 0.171 & 0.197 & 0.77 \\
\hline
\end{tabular}

Table 5. Assessment of the collinearity of internal constructs.

\begin{tabular}{|c|c|c|c|c|}
\hline VIF & CSR Economic & $\begin{array}{c}\text { CSR } \\
\text { Environmental }\end{array}$ & CSR Social & $\begin{array}{c}\text { Business } \\
\text { Profitability }\end{array}$ \\
\hline CSR Economic & & & & 1.442 \\
\hline CSR Environmental & & & & 1.839 \\
\hline CSR Social & & & & 1.419 \\
\hline Business profitability & & & & \\
\hline
\end{tabular}

Based on the results presented in Table 3; Table 4, it is viable to indicate that it has not been necessary to eliminate any indicator of the construct in Mode A "Business Profitability", because of all the requirements listed by the technique.

Now it will continue, with debugging of the indicators of the composite constructs in Mode B. First, following [152] those indicators that had a high collinearity have been eliminated, then the indicators that do not have a significant weight $(p>0.05)$ have been removed, and also did not provide improvements in the explained variance of the model $[153,154]$, and for this, a bootstrapping with 10,000 iterations and two tails has been performed. In this process, the indicators SOC. 4, SOC. 6, SOC. 8, SOC. 10 of the CSR social construct, ENV.1, ENV.3, ENV 5, ENV.6 of CSR environmental dimension, and Eco. 2 of CSR economic have been eliminated. The results are shown in Table A1. 
Next, in Figure 2, we can see the debugging model that we have used for the hypothesis contrast.

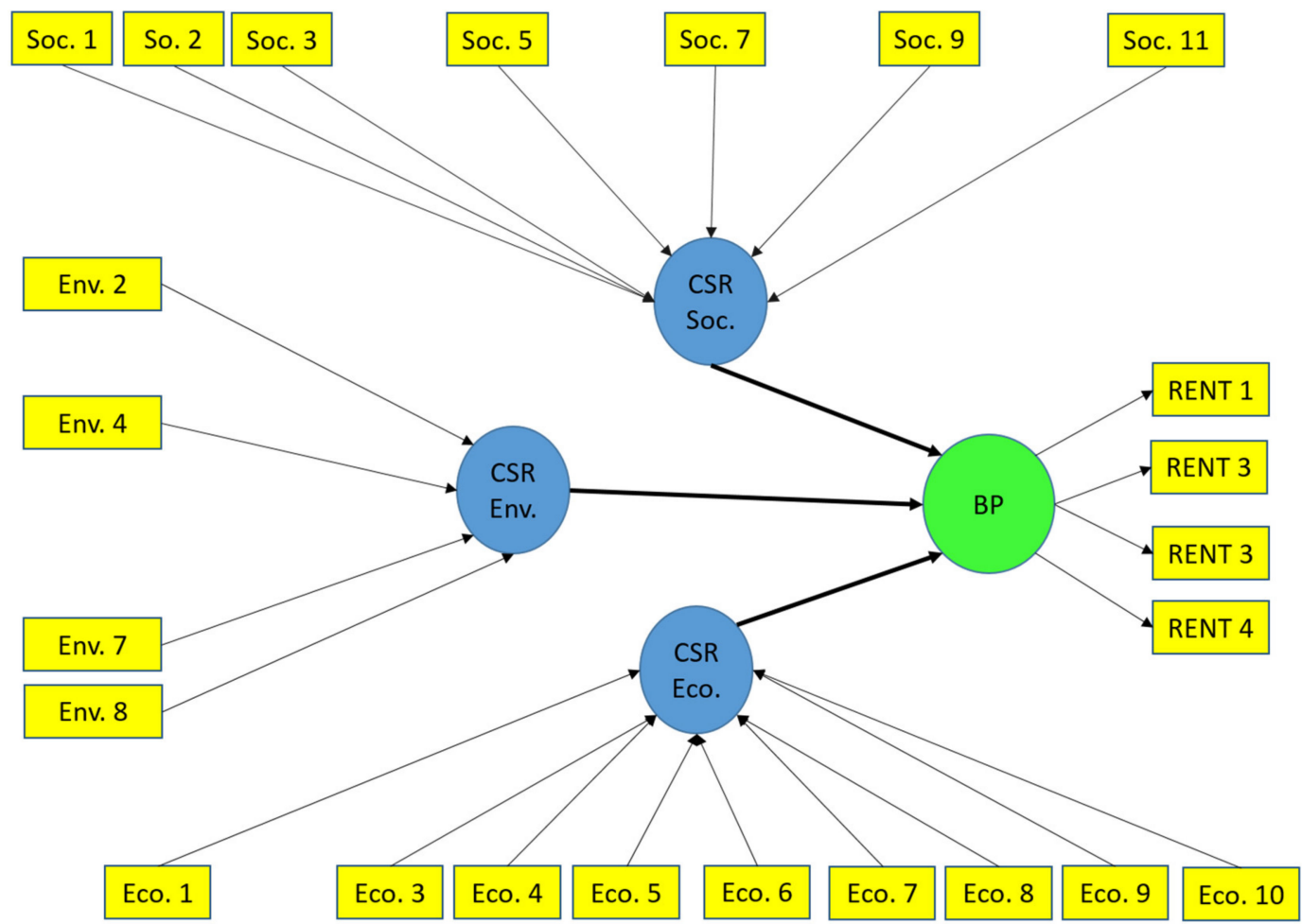

Figure 2. Model purified and used to contrast the hypotheses.

Next, the model as a whole will be assessed in order to validate the structural model and the result of the hypothesis contrast obtained, for this, first, the PLS algorithm is executed to obtain the VIF of the constructs, then bootstrapping with 10,000 iterations, one queue, and bootstrap percentile configuration will be shown to make the hypothesis contrast. Finally, blindfolding will be executed to analyze the predictive capacity of the proposed model.

At this point (see Table 5), it is verified that there is no collinearity between the constructs because the variance inflation factor (VIF) is less than 5 [144] (p. 170). Once here, and in order to assess the predictive capacity of the model, it is required that it has an $\mathrm{R}^{2}>0.1$ and also that $\mathrm{Q}^{2}>0$. Both requirements are met, therefore, the model is valid and has predictive capacity on the dependent variable. In addition, as shown in Table 6, most of the variance explained by the model comes from the "CSR. Economic". With a value of $11.97 \%$, followed by the "CSR. Social" that contributes $10.28 \%$ to the explained variance of the "Business Profitability", therefore, both constructs, have a positive contribution to the dependent construct, although it is true and the variance explained by the entire model reaches $19.8 \%$. There is a large part of the variance of this one that comes from other variables external to the model. A fact that must be considered and that is consistent, since the profitability of the company also depends on other variables.

Table 6. $\mathrm{R}^{2}$ level evaluation of the model.

\begin{tabular}{|c|c|c|c|c|c|}
\hline Hypothesis & $\mathbf{R}^{2}$ & $\mathrm{Q}^{2}$ & Path & Correlation & $\begin{array}{l}\text { Variance } \\
\text { Explained }\end{array}$ \\
\hline H1. CSR. Social $\rightarrow$ Profitability & & & 0.297 & 0.346 & $10.28 \%$ \\
\hline H2. CSR. Environmental $\rightarrow$ Profitability & & & -0.101 & 0.242 & $-2.44 \%$ \\
\hline H3. CSR. Economic $\rightarrow$ Profitability & & & 0.327 & 0.366 & $11.97 \%$ \\
\hline Business Profitability & 0.198 & 0.082 & & & \\
\hline
\end{tabular}


In Table 7, the data obtained from the contrast of the hypothesis, where it should be noted that the hypothesis with greater significance is Hypothesis 3, which relates to the "CSR. Economic" with "Corporate Profitability", followed by Hypothesis 1, which relates to the "CSR. Social" with the "Business Profitability", the two with a level of significance of over $99 \%$.

Table 7. Contrast of hypotheses according to their "Path Coefficient".

\begin{tabular}{|c|c|c|c|c|c|}
\hline \multirow{2}{*}{ Hypothesis } & \multicolumn{2}{|c|}{ Confidence Intervals } & \multirow{2}{*}{$\begin{array}{l}\text { Coefficient } \\
\text { Path }\end{array}$} & \multirow{2}{*}{ Statistical $\mathbf{t}$} & \multirow{2}{*}{$\begin{array}{l}\text { Evaluation of } \\
\text { the Hypothesis }\end{array}$} \\
\hline & $5 \%$ & $95 \%$ & & & \\
\hline H1. CSR. Social $\rightarrow$ Profitability & 0.284 & 0.436 & 0.297 & $2.538^{* * *}$ & ACCEPTED \\
\hline H2. CSR. Environmental $\rightarrow$ Profitability & -0.101 & 0.230 & -0.101 & $0.869 \mathrm{~ns}$ & REJECTED \\
\hline H3. CSR. Economic $\rightarrow$ Profitability & 0.194 & 0.436 & 0.327 & $3.751 * * *$ & ACCEPTED \\
\hline
\end{tabular}

$$
{ }^{* * *} p(0.01) ;{ }^{* *} p(0.05) ;{ }^{*} p(0.1) \text {; ns: Not significant; t: Student one-tailed t-test. }
$$

On the contrary, it is necessary to emphasize that the "CSR. Environmental" does not provide a significant influence on the "Business Profitability", and, therefore, Hypothesis 2 is rejected, both by the "Path coefficient", by the "Statistical $t$ ", and by the "Confidence Intervals". In addition, the contribution to the explained variance of this relation on the dependent variable is very low, being able to affirm that, from the analyzed data, this construct has a null contribution to the "Business Profitability", data and contribution that can be very interesting.

To conclude with the analysis of the results, we have done Importance-Performance Map Analysis (IPMA), for analyzing the value score for "performance" with the estimation "importance" total effects $[155,156]$ (see Table 8 ).

Table 8. Performance/indicator relation over business profitability.

\begin{tabular}{cc}
\hline Indicator & Performance \\
RENT 4_Profit margin & 96.577 \\
ECO. 6 Code of Ethics and Conduct & 66.019 \\
ECO. 1 Inclusion of mission, values and CSR vision & 59.223 \\
ECO. 7 Relationship with suppliers & 52.427 \\
RENT 2_Profitability on capital employed & 51.969 \\
ENV. 4 Waste management & 51.456 \\
SOC. 7 Equal opportunity & 50.485 \\
SOC. 9 Occupational Health \& Safety & 49.515 \\
RENT 1_Profitability on own resources & 45.073 \\
RENT 3_Profitability on total assets & 42.244 \\
ECO. 8 Information transparency & 39.806 \\
ECO. 4 Compliance with the United Nations Global Compact & 38.835 \\
SOC. 1 Assistance and social benefits & 37.864 \\
SOC. 11 Clients satisfaction & 37.864 \\
SOC. 2 Sponsorship and patronage & 32.039 \\
ECO. 10 Value creation management model & 31.068 \\
ECO. 9 ODS & 30.097 \\
ECO. 3 Included in sustainable indexes & 26.214 \\
SOC. 5 Employment for disabled personnel & 24.272 \\
ENV. 7 included in CDP & 22.330 \\
SOC. 3 Foundation & 17.476 \\
ECO. 5 Cost reduction & 13.592 \\
ENV. 8 Environmental training & 11.650 \\
\hline
\end{tabular}

In Table 8, we can see how the indicator of the highest performance is "RENT 4_Profit margin", followed by three indicators of the economic block "ECO. 6 Code of Ethics and Conduct", "ECO. 1 Inclusion of mission, values and CSR vision", and "ECO. 7 Relationship with suppliers", the first of the 
Environment is "ENV. 4 Waste management" and the first of the Social is "SOC. 7 Equal opportunity", all of them with a yield greater than $50 \%$.

On the other hand, the indicators that yield less performance to the company's profitability (all less than 15\%) are "ECO. 5 Cost reduction", "ENV. 2 Performance of environmental audits", and "ENV. 8 Environmental training", where the latter, provides only $7.7 \%$ yield. This information can be very useful for companies when choosing items that are more profitable to invest.

\section{Discussion and Conclusions}

The positive effects of implementing CSR measures in companies are undeniable [48] not only to increase the competitiveness of companies but also from the care of employees [44,103] and the increase in reputation [53], as well as legitimacy [38].

In this sense, companies listed on the Spanish stock market should use the disclosure of CSR information not only as a way to make their management more transparent but as a differentiating element both in the valuation of socially responsible investments and in manifesting in a way to explicitly commit to your stakeholders.

Therefore, applying the PLS-SEM methodology on the 103 companies that are listed on the Spanish continuous market, it has been shown that the disclosure on the implementation of CSR measures presents a significant relationship with business profitability, achieving the model that proposed a predictive capacity $19.8 \%$ overall. According to the different dimensions analyzed, it is found that both the disclosure about CSR in the social and economic field has a positive influence on business profitability, presenting a predictive capacity of $10.28 \%$ and $11.97 \%$, respectively, with a confidence superior to $99 \%$. In this way, the assumption is confirmed that, if the stakeholders perceive an increase in the value of the company due to the disclosure of the CSR measures that it implements, that increase is compensated by an increase in profits for the company, and, therefore, of its business profitability. This result is in line with that obtained by [3,4,14,16,42,75-94].

However, analyzing the influence of the disclosure of the implementation of CSR measures in their environmental dimension is rejected as neither positive nor negative effect of the implementation of CSR measures found in the environmental dimension on business profitability. This result is in the line of works such as $[74,157,158]$. It shows that the disclosure of environmental investments is not immediately reflected in an increase in business performance. Following [84] it shows how responsible investments are not always as productive as desired. Likewise, another possible explanation for the result obtained may come from the work of [159], who emphasize that the implementation of CSR measures in the environmental field can be connected with profitability only in a specific context in that management options are more important in certain types of environments. However, although it has not found that the disclosure of the implementation of CSR measures in their environmental dimension positively influences business profitability, it has not found to have a significant negative effect. In this way, it is not demonstrated that the investment made in environmental CSR harms business results, which means that the implementation of CSR measures in their environmental dimension does not harm business profitability, but they do generate a competitive advantage [160]. What begins as a competitive advantage without improving business profitability, may in the near future improve the company's competitive capacity [1].

Based on all the results obtained, it can be determined that the disclosure of the implementation of CSR measures does not harm business profitability. Therefore, the fact that many businessmen and managers do not implement CSR measures because they consider it an expense that would reduce their profitability is not justified, demonstrating that the investment in CSR can only have positive effects on business or neutral profitability, even though all the cases are a source of competitive advantages [7].

As a result of the study and given the importance of transparency and the disclosure of CSR information of companies, this paper presents as a main finding the importance of disclosing this information, since they will not only affect the reputation and legitimacy of companies but also significantly affect business profitability. 
Author Contributions: Conceptualization, S.E.-S., P.P.-C., and J.P.-V.; Methodology, A.F.-P. and J.P.-V.; Software, A.F.-P. and J.P.-V.; Validation, A.F.-P. and J.P.-V.; Formal analysis, S.E.-S. and J.P.-V.; Investigation, S.E.-S. and J.P.-V.; Resources, S.E.-S. and J.P.-V.; Data curation, A.F.-P. and J.P.-V.; Writing-original draft preparation, S.E.-S., J.P.-V., P.P.-C., and A.F.-P.; Writing—review and editing, S.E.-S., J.P.-V., P.P.-C., and A.F.-P.; Visualization, J.P.-V.; Supervision, S.E.-S. and J.P.-V.; Project administration, S.E.-S.

Funding: This research received no external funding.

Conflicts of Interest: The authors declare no conflict of interest.

\section{Appendix A}

Table A1. Validity of indicators Mode B.

\begin{tabular}{|c|c|c|c|}
\hline \multirow{2}{*}{ Indicators Mode B } & \multirow{2}{*}{ VIF } & Weight & \multirow{2}{*}{ Charges } \\
\hline & & $p$-Values & \\
\hline ECO. 1 Inclusion of mission, values, and CSR vision $\rightarrow$ CSR Economic & 2.3 & 0.152 & 0.694 \\
\hline ECO. 3 Included in sustainable indexes $\rightarrow$ CSR Economic & 1.977 & 0.348 & 0.546 \\
\hline ECO. 4 Compliance with the United Nations Global Compact $\rightarrow$ CSR Economic & 2.65 & 0.747 & 0.445 \\
\hline ECO. 5 Cost reduction $\rightarrow$ CSR Economic & 1.305 & 0.023 & -0.079 \\
\hline ECO. 6 Code of Ethics and Conduct $\rightarrow$ CSR Economic & 1.529 & 0.559 & 0.376 \\
\hline ECO. 7 Relationship with suppliers $\rightarrow$ CSR Economic & 2.552 & 0.197 & 0.797 \\
\hline ECO. 8 Information transparency $\rightarrow$ CSR Economic & 3.297 & 0.266 & 0.682 \\
\hline ECO. 9 ODS $\rightarrow$ CSR Economic & 2.969 & 0.404 & 0.431 \\
\hline ECO. 10 Value creation management model $\rightarrow$ CSR Economic & 2.172 & 0.688 & 0.45 \\
\hline ENV. 2 Performance of environmental audits $\rightarrow$ CSR Environmental & 1.283 & 0.582 & 0.44 \\
\hline ENV. 4 Waste management $\rightarrow$ CSR Environmental & 1.482 & 0.324 & 0.807 \\
\hline ENV. 7 included in CDP $\rightarrow$ CSR Environmental & 1.358 & 0.106 & 0.749 \\
\hline ENV. 8 Environmental training $\rightarrow$ CSR Environmental & 1.139 & 0.435 & 0.447 \\
\hline SOC. 1 Assistance and social benefits $\rightarrow$ CSR Social & 2.096 & 0.513 & 0.305 \\
\hline SOC. 2 Sponsorship and patronage $\rightarrow$ CSR Social & 1.912 & 0.44 & 0.471 \\
\hline SOC. 3 Foundation $\rightarrow$ CSR Social & 1.069 & 0.003 & 0.762 \\
\hline SOC. 5 Employment for disabled personnel $\rightarrow$ CSR Social & 1.337 & 0.33 & 0.084 \\
\hline SOC. 7 Equal opportunity $\rightarrow$ CSR Social & 2.322 & 0.179 & 0.634 \\
\hline SOC. 9 Occupational Health and Safety $\rightarrow$ CSR Social & 2.473 & 0.844 & 0.416 \\
\hline SOC. 11 Clients satisfaction $\rightarrow$ CSR Social & 1.743 & 0.371 & 0.226 \\
\hline
\end{tabular}

\section{References}

1. Gémar, G.; Espinar, D. Communication about corporate social responsibility practices and return on equity. Revista de Empresa Familiar 2015, 5, 7-15. [CrossRef]

2. Salaiz, A.; Evans, K.; Pathak, S.; Vera, D. The impact of corporate social responsibility and irresponsibility on firm performance: New insights to an old question. Organ. Dyn. 2019. [CrossRef]

3. Hernández-Perlines, F.; Sánchez-Infantes, J.P. Análisis del efecto de la responsabilidad social empresarial en los resultados empresariales de las micro, pequeñas y medianas empresas (mipymes). J. Glob. Compet. Gov. 2016, 10, 110-123.

4. Bragdon, J.H.; Marlin, J. Is pollution profitable? Risk Manag. 1972, 19, 9-18.

5. Moskowitz, M. Choosing socially responsible stocks. Bus. Soc. Rev. 1972, 1, 72-75.

6. Escamilla, S.; Casado, P.; Flores, S. Análisis de la divulgación de la información sobre la responsabilidad social corporativa en las empresas de transporte público urbano en España. Revista de Contabilidad-Spanish Accounting Review 2016, 19, 195-203. [CrossRef]

7. Husted, B.W.; Allen, D.B. Is It Ethical to use ethics and strategy? J. Bus. Ethics 2000, 27, 21-31. [CrossRef]

8. Caputo, F.; Pizzi, S. Ethical firms and web reporting: Empirical evidence about the voluntary adoption of the Italian "legality rating". Int. J. Bus. Manag. 2019, 14, 36-45. [CrossRef]

9. Dumay, J.; La Torre, M.; Farneti, F. Developing trust through stewardship: Implications for intellectual capital, integrated reporting, and the EU Directive 2014/95/EU. J. Intellect. Cap. 2019, 20, 11-39. [CrossRef]

10. Navarro, A.; Alcaraz, F.J.; Ortiz, D. La divulgación de la información sobre responsabilidad corporativa en administraciones públicas: Un estudio empírico en gobiernos locales. Revista de Contabilidad—Spanish Accounting Review 2010, 13, 285-314. [CrossRef] 
11. Dhaliwal, D.S.; Radhakrishnan, S.; Tsang, A.; Yang, Y.G. Divulgación no financiera y precisión del pronóstico del analista: Evidencia internacional sobre divulgación de responsabilidad social corporativa. Account. Rev. 2012, 87, 723-759. [CrossRef]

12. Gamerschlag, R.; Möller, K.; Verbeeten, F. Determinantes de la divulgación voluntaria de RSE: Evidencia empírica de Alemania. Rev. Manag. Sci. 2011, 5, 233-262. [CrossRef]

13. Garriga, E.; Melé, D. Corporate social responsibility theories: Mapping the territory. J. Bus. Ethics 2004, 53, 52-71. [CrossRef]

14. Alvarado, A.; Bigné, E.; Currás, R. Theoretical perspectives for studying corporate social responsibility: A rationality-based classification. Estud. Gerenc. 2011, 27, 115-138.

15. Escamilla, S.; Jiménez, I.; Prado, C. La Responsabilidad Social Empresarial, Una Forma de Crear Valor: El Camino Hacia un Mundo Mejor; Editorial Académica Española: Madrid, España, 2013.

16. McWilliams, A.; Siegel, D. Corporate social responsibility: A theory of the firm perspective. Acad. Manag. Rev. 2001, 26, 117-127. [CrossRef]

17. Barnett, M.L. Stakeholder influence capacity and the variability of financial returns to corporate social responsibility. Acad. Manag. Rev. 2007, 32, 794-816. [CrossRef]

18. Bowen, H. Social Responsibility of Businessman; Harper \& Brothers: New York, NY, USA, 1971.

19. Sethi, S.P. Dimensions of Corporate Social Performance: An Analytical Framework. Calif. Manag. Rev. 1975, 17, 58-64. [CrossRef]

20. Carroll, A.B. A three-dimensional conceptual model of corporate performance. Acad. Manag. Rev. 1979, 4, 497-505. [CrossRef]

21. Drucker, P.F. The new meaning of corporate social responsibility. Calif. Manag. Rev. 1984, $26,53-63$. [CrossRef]

22. Farmer, R.; Hogue, W. Corporate Social Responsibility; Lexington, KY, USA, 1985.

23. Wood, D.J. Corporate social performance revisited. Acad. Manag. Rev. 1991, 16, 691-718. [CrossRef]

24. Boatright, J.R. Ethics and the Conduct of Business; Pearson: NJ, USA, 1993.

25. Porter, M.E.; Kramer, M.R. La filantropía empresarial como ventaja competitiva. Harv. Deusto Bus. Rev. 2003, 80, 7-20.

26. De la Cuesta, M.; Valor, C. Fostering corporate social responsibility through public initiative: From the EU to the Spanish case. J. Bus. Ethics 2004, 55, 275-293.

27. Toro, D. El enfoque estratégico de la RSC: Revisión de la literatura académica. Intang. Cap. 2006, 14, 338-358.

28. Valderrama, J.A. Reflexiones en torno a la responsabilidad social de las empresas. Teoría y Praxis 2007, 3, 125-134. [CrossRef]

29. Hayek, F.A. The Corporation in a Democratic Society: In Whose Interest Ought It and Will It be Run? McGraw-Hill: New York, NY, USA, 1960.

30. Friedman, M. The social responsibility of Business is to increase its profits. The New York Times Magazine, 13 September 1970; 32-33.

31. Freeman, R.E. Strategic Management: A Stakeholder Approach; Pitman Publishing Inc.: Marshfield, MA, USA, 1984.

32. Kliksberg, B. Ética empresarial:¿Moda o demanda imparable? Fundación Carolina: Washington, DC, USA, 2006.

33. Mcguire, J. Business and Society; McGraw Hill: New York, NY, USA, 1963.

34. Robbins, S.P. Comportamiento Organizacional; Prentice Hall: Ciudad de México, México, 1994.

35. Méndez, M. Ética y responsabilidad social corporativa. Ética y Economía. ICE 2005, 823, 141-155.

36. Rodríguez, M.A.; Ricart, J.E.; Sánchez, P. Sustainable Development and Sustainability of Competitive Advantage: A Dynamic and Sustainable View of the Firm. Create. Innov. Manag. 2002, 11, 135-146. [CrossRef]

37. Cortés, F. Ética empresarial y responsabilidad social empresarial. Boletín Económico de ICE 2008, 33-47.

38. Díez, F.; Blanco, A.; Cruz, A.; Prado, C. Efecto de la responsabilidad social empresarial sobre la legitimidad de las empresas. Anuario Jurídico y Económico Escurialense 2014, 47, 325-348.

39. Inoue, Y.; Lee, S. Effects of different dimensions of corporate social responsibility on corporate financial performance in tourism-related industries. Tour. Manag. 2011, 32, 790-804. [CrossRef]

40. Clarkson, M.E. A stakeholder framework for analyzing and evaluating corporate social performance. Acad. Manag. Rev. 1995, 20, 92-117. [CrossRef] 
41. Peloza, J.; Papania, L. The missing link between corporate social responsibility and financial performance: Stakeholder salience and identification. Corp. Reput. Rev. 2008, 11, 169-181. [CrossRef]

42. Martínez-Campillo, A.; Cabeza-García, L.; Marbella-Sánchez, F. Responsabilidad social corporativa y resultado financiero: Evidencia sobre la doble dirección de la causalidad en el sector de las Cajas de Ahorros. Cuadernos de Economía y Dirección de la Empresa 2012, 16, 54-68. [CrossRef]

43. Vaca, R.M.; Moreno, M.J.; Riquel, F. Análisis de la responsabilidad social corporativa desde tres enfoques: Stakeholders, capital intelectual y teoría institucional. In Conocimiento, Innovación y Emprendedores: Camino al Futuro; Universidad de la Rioja, Grupo de Investigación Fedra: Logroño, Spain, 2007.

44. Rodrigo, P.; Arenas, D. Do employees care about CSR programs? A typology of employees according to their attitudes. J. Bus. Ethics 2008, 83, 265-283. [CrossRef]

45. Olcese, A.; Rodriguez, M.A.; Alfaro, J. Manual de la Empresa Responsable y Sostenible; McGraw-Hill: Madrid, España, 2008.

46. Atkinson, A.; Waterhouse, J.; Wells, R. A stakeholder approach to strategic performance measurement. Sloan Manag. Rev. 1997, 38, 25-37.

47. Hillman, A.; Keim, G. Shareholder value, stakeholder management and social issues: What's the bottom line? Strateg. Manag. J. 2001, 22, 125-139. [CrossRef]

48. Dentchev, N.A. Corporate social performance as a business strategy. J. Bus. Ethics 2004, 55, $397-412$. [CrossRef]

49. Hall, R. The strategic analysis of intangibles resources. Strateg. Manag. J. 1992, 13, 135-144. [CrossRef]

50. Hall, R. A framework linking intabigle resources and capabilities to sustainable competitive advantage. Strateg. Manag. J. 1993, 14, 607-618. [CrossRef]

51. Shamsie, J. The Context of Dominance: An Industry-Driven Framework for Exploiting Reputation. Strateg. Manag. J. 2003, 24, 199-215. [CrossRef]

52. López, V.A.; Iglesias, S. Percepciones directivas Del recurso de reputación. Un estudio empírico de sus relaciones con el rendimiento empresarial. Cuadernos de Economía y Dirección de la Empresa 2006, 28, 139-160.

53. Martínez, I.; Olmedo, I. Revisión teórica de la reputación en el entorno empresarial. Cuadernos de Economía y Dirección de la Empresa 2010, 44, 59-77. [CrossRef]

54. Sen, S.; Bhattacharya, C.B. Does doing good always lead to doing better? J. Mark. Res. 2001, 38, $225-243$. [CrossRef]

55. Bigné, E.; Andreu, L.; Chumpitaz, R.; Swaen, V. Percepción de la responsabilidad social corporativa: Un análisis cross-cultural. Universia Bus. Rev. 2005, 5, 14-27.

56. Grant, R.M. The Resource-Based Theory of Competitive Advantage: Implications for Strategy Formulation. Calif. Manag. Rev. 1991, 33, 233-258. [CrossRef]

57. González, E.; García, D. La responsabilidad social empresarial (RSE) en Europa: La apuesta por un modelo de empresa. Una revisión crítica desde la ética empresarial. RECERCA, Revista de Pensament i Anàlisi 2006, $6,157-170$.

58. Al-Ajmi, J.; Hussain, H.; Al-Saleh, N. Clients of conventional and Islamic banks in Bahrain: How they choose which bank to patronize. Int. J. Soc. Econ. 2009, 36, 1086-1112. [CrossRef]

59. Piñeiro, P.; Quintas, M.A.; Caballero, G. Incidencia de la proactividad medioambiental en el rendimiento de las empresas constructoras españolas. Revista Europea de Dirección y Economía de la Empresa 2009, 18, 79-106.

60. Hamilton, J.T. Pollution as news: Media and stock market reactions to the toxic release inventory data. J. Environ. Econ. Manag. 1995, 28, 98-113. [CrossRef]

61. Hart, S.L.; Ahuja, G. Does it pay to be green? An empirical examination of the relationship between emission reduction and firm performance. Bus. Strategy Environ. 1996, 5, 30-37. [CrossRef]

62. Angla-Jimenez, J.; Seto-Pamies, D. La naturaleza de la relación entre la responsabilidad social de la empresa (RSE) y el resultado financiero. Revista Europea de Dirección y Economía de la Empresa 2011, 20, 161-176.

63. Cañón, J.; Garcés, C. Repercusión económica de la certificación medioambiental ISO14001. Cuadernos de Gestión 2006, 6, 45-62.

64. Carmona, E.; Céspedes, J.; De Burgos, J. Environmental strategies in spanish hotels: Contextual factors and performance. Serv. Ind. J. 2004, 24, 101-130. [CrossRef]

65. Bansal, P.; Clelland, I. Talking trash: Legitimacy, impression management, and unsystematic risk in the context of the natural environment. Acad. Manag. J. 2004, 47, 93-103. 
66. García-Rodríguez, F.J.; Armas-Cruz, Y. Aproximación a la incidencia de la responsabilidad social-medioambiental en el rendimiento económico de la empresa hotelera española. Revista Europea de Dirección y Economía de la Empresa 2007, 16, 47-66.

67. Vance, S.C. Are socially responsible corporations good investment risks? Manag. Rev. 1975, 64, $19-24$.

68. Walley, N.; Whitehead, B. It's not easy being green. Harv. Bus. Rev. 1994, 72, 46-52.

69. Cordeiro, J.J.; Sarkis, J. Environmental proactivism and firm performance: Evidence from security analyst earnings forecasts. Bus. Strategy Environ. 1997, 6, 104-114. [CrossRef]

70. Wright, P.; Ferris, S.P. Agency conflict and corporate strategy: The effect of divestment on corporate value. Strateg. Manag. J. 1997, 18, 77-83. [CrossRef]

71. Korten, D.C. When Corporations Rule the World; Berrett-Koehler Publishers: San Francisco, USA, 2001.

72. Brammer, S.; Millington, A. Does it pay to be different? An analysis of the relationship between corporate social and financial performance. Strateg. Manag. J. 2008, 29, 1325-1343. [CrossRef]

73. Nelling, E.; Webb, E. Corporate social responsibility and financial performance: The "virtuous circle" revisited. Rev. Quant. Financ. Account. 2009, 32, 197-209. [CrossRef]

74. Achim, M.V.; Borlea, N.S. Environmental performances-way to boost up financial performances of companies. Environ. Eng. Manag. J. 2014, 13, 991-1005. [CrossRef]

75. Heinze, D.C. Financial correlates of a social involvement measure. Akron Bus. Econ. Rev. 1976, 7, 48-51.

76. Sturdivant, F.D.; Ginter, J.L. Corporate social responsiveness: Management attitudes and economic performance. Calif. Manag. Rev. 1977, 19, 30-39. [CrossRef]

77. Youndt, M.A.; Snell, S.A.; Dean, J.W.; Lepak, D.P. Human resource management, manufacturing strategy, and firm performance. Acad. Manag. J. 1996, 39, 836-866.

78. Waddok, S.A.; Graves, S.B. The corporate social performance-Financial performance link. Strateg. Manag. J. 1997, 18, 303-319. [CrossRef]

79. Griffin, J.J.; Mahon, J.F. The corporate social performance and corporate financial performance debate: Twenty-five years of incomparable research. Bus. Soc. 1997, 36, 5-31. [CrossRef]

80. Preston, L.E.; O' bannon, D. The corporate social-financial performance relationship: A typology and analysis. Bus. Soc. 1997, 36, 419-429. [CrossRef]

81. Russo, M.V.; Fouts, P.A. A resource based perspective on corporate environmental performance and profitability. Acad. Manag. J. 1997, 40, 534-559.

82. Judge, W.Q.; Douglas, T.J. Performance implications of incorporating natural environmental issues into the strategic planning process: An empirical assessment. J. Manag. Stud. 1998, 35, 241-262. [CrossRef]

83. Orlitzky, M.; Schmidt, F.; Rynes, S. Corporate social and financial performance: A meta-analysis. Organ. Stud. 2003, 24, 403-441. [CrossRef]

84. Porter, M.E.; Kramer, M.R. Strategy and society: The link between competitive advantage and corporate social responsibility. Harv. Bus. Rev. 2006, 84, 78-92. [PubMed]

85. García-Rodríguez, F.J.; Armas-Cruz, Y. Relation between social-environmental responsibility and performance in hotel firms. Int. J. Hosp. Manag. 2007, 26, 824-839. [CrossRef]

86. Angla-Jimenez, J.; Seto-Pamies, D. Responsabilidad social corporativa y resultado financiero: Un análisis empírico. In Administrando en Entornos Inciertos; XXIII Congreso Anual AEDEM: Sevilla, España, 2009.

87. Surroca, J.; Tribó, J.A.; Waddock, S. Corporate responsibility and financial performance: The role of intangible resources. Strateg. Manag. J. 2010, 31, 463-490. [CrossRef]

88. García-Castro, R.; Arino, M.A.; Canela, M.A. Does social performance really lead to financial performance? Accounting for endogeneity. J. Bus. Ethics 2010, 92, 107-126. [CrossRef]

89. Perrini, F.; Russo, A.; Tencati, A.; Vurro, C. Deconstructing the relationship between corporate social and financial performance. J. Bus. Ethics 2011, 102, 59-76. [CrossRef]

90. Fisher-Vanden, K.; Thorburn, K.S. Voluntary corporate environmental initiatives and shareholder wealth. J. Environ. Econ. Manag. 2011, 62, 430-445. [CrossRef]

91. Gallardo-Vázquez, D.; Sánchez-Hernández, M.I.; Corchuelo-Martinez-Azua, M.B. Validación de un instrumento de medida para la relación entre la orientación a la responsabilidad social corporativa y otras variables estratégicas de la empresa. Revista de Contabilidad 2013, 16, 11-23. [CrossRef]

92. Larrán, M.; Herrera, J.; Martínez, D. Relación entre la RSE y el performance competitivo en la pequeña y mediana empresa: Un estudio empírico. AECA: Revista de la Asociación Española de Contabilidad y Administración de Empresas 2013, 104, 9-12. 
93. Valenzuela Fernández, L.; Jara-Bertin, M.; Villegas Pineaur, F. Prácticas de responsabilidad social, reputación corporativa y desempeño financiero. Revista de Administração de Empresas 2015, 55, 329-344. [CrossRef]

94. Miras-Rodríguez, M.M.; Carrasco-Gallego, A.; Escobar-Pérez, B. Are socially responsible behaviors paid off equally? A Cross-cultural analysis. Corp. Soc. Responsib. Environ. Manag. 2015, 22, 237-256. [CrossRef]

95. Friedman, M. Capitalism and Freedom; University of Chicago Press: Chicago, IL, USA, 1962.

96. Abbott, W.F.; Monsen, R.J. On the measurement of corporate social responsibility: Self-reported disclosures as a method of measuring corporate social involvement. Acad. Manag. J. 1979, 22, 501-515.

97. Alexander, G.J.; Buchholz, R.A. Corporate social responsibility and stock market performance. Acad. Manag. J. 1978, 21, 479-486. [CrossRef]

98. Aupperle, K.E.; Carroll, A.B.; Hatfield, J.D. An empirical examination of the relationship between corporate social responsibility and profitability. Acad. Manag. J. 1985, 28, 446-463.

99. Williams, H.E.; Medhurst, J.; Drew, K. Corporate strategies for a sustainable future. In Environmental Strategies for Industry: International Perspectives on Research Needs and Policy Implications; Island Press: Washington, DC, USA, 1993; pp. 117-146.

100. Stanwick, P.; Stanwick, S. The relationship between corporate social performance, and organizational size, financial performance, and environmental performance: An empirical examination. J. Bus. Ethics 1998, 17, 195-204. [CrossRef]

101. Teoh, S.H.; Welch, I.; Wazzan, C.P. The Effect of Socially Activist Investment Policies on the Financial Markets: Evidence from the South African Boycott. J. Bus. 1999, 72, 35-89. [CrossRef]

102. Thornton, D.; Kagan, R.A.; Gunningham, N. Sources of corporate environmental performance. Calif. Manag. Rev. 2003, 46, 127-141. [CrossRef]

103. Clacher, I.; Hagendorff, J. Do announcements about corporate social responsibility create or destroy shareholder wealth? Evidence from the UK. J. Bus. Ethics 2012, 106, 253-266. [CrossRef]

104. Madorran, C.; Garcia, T. Corporate social responsibility and financial performance: The Spanish case. Revista de Administração de Empresas 2016, 56, 20-28. [CrossRef]

105. Bravo, R.; Matute, J.; Pina, J.M. Corporate social responsibility as a vehicle to reveal the corporate identity: A study focused on the websites of Spanish financial entities. J. Bus. Ethics 2011, 107, 129-146. [CrossRef]

106. Pérez-Bustamante, D.; Rodríguez, B.; Medrano, M.L. Análisis de la dimensión medioambiental de las compañías aéreas que operan en España: Estudio del contenido de sus páginas web. Obs. Medioambient. 2011, 14, 211-224. [CrossRef]

107. Celma, D.; Martínez, E.; Coenders, G. Corporate Social Responsibility in Human Resource Management: An analysis of common practices and their determinants in Spain. Corp. Soc. Responsib. Environ. Manag. 2012, 21, 82-99. [CrossRef]

108. Fuentes, F.J.; Nuñez, J.; Veroz, R. Alternativas de cumplimiento de la responsabilidad social corporativa en gestión de recursos Humanos. Universia Bus. Rev. 2005, 7, 68-89.

109. Vassilikopoulou, A.; Siomkos, G.; Chatzipanagiotou, K.; Pantouvakis, A. Product-harm crisis management: Time heals all wounds? J. Retail. Consum. Serv. 2009, 16, 174-180. [CrossRef]

110. Crowther, D.; Duarte-Atoche, T. Responsabilidad social y discapacidad intelectual. Revista Internacional de Sociología (RIS) 2014, 72, 45-70. [CrossRef]

111. Aragón, J.; Rocha, F.; Cruces, J. La dimensión laboral de la RSC en España: Un análisis de casos. Cuadernos de información sindical: La dimensión laboral de la Responsabilidad Social de las Empresas 2005, 63, 33-70.

112. Aldeanueva, I. La responsabilidad social como elemento de cohesión en la integración de los sistemas de gestión. Revista de Dirección y Administración de Empresas 2012, 19, 9-28.

113. Mañas-Viniegra, L. El voluntariado corporativo en la estrategia de responsabilidad social de las empresas del IBEX 35. Retos. Revista de Ciencias en la Administración y Economía 2018, 16, 19-32.

114. Vila, N.; Gimeno- Martínez, C. Efectos de la RSC sobre el consumidor: Una aplicación al sector público terrestre. Innovar 2010, 20, 235-255.

115. Larrinaga-González, C.; Pérez-Chamorro, V. Sustainability accounting and accountability in public water companies. Public Money Manag. 2008, 28, 337-343. [CrossRef]

116. Miles, M.P.; Munilla, L.S.; Russell, G.R. Marketing and environmental registration/certification what industrial marketers should understand about ISO 14000. Ind. Mark. Manag. 1997, 26, 363-370. [CrossRef]

117. Alonso-Cañadas, J.; Saraite-Sariene, L.; Haro-de-Rosario, A.; Caba-Pérez, M.C. Análisis de las memorias de sostenibilidad de la banca internacional. REICE 2018, 11, 49-75. [CrossRef] 
118. Aldás, J.; Andreu, L.; Currás, R. La responsabilidad social como creadora de valor de marca: El efecto moderador de la atribución de objetivos. Revistas Europea de Dirección y Economía de la Empresa 2013, 22, 21-28. [CrossRef]

119. Becchetti, L.; Salustri, F.; Scaramozzino, P. Making information on CSR scores salient: A randomized field experiment. Oxf. Bull. Econ. Stat. 2019, 81, 1193-1213. [CrossRef]

120. Arribas, I.; Espinós-Vañó, M.D.; García, F.; Morales-Bañuelos, P.B. The Inclusion of Socially Irresponsible Companies in Sustainable Stock Indices. Sustainability 2019, 11, 2047. [CrossRef]

121. Moreno, A.; Caprotti, P. La comunicación de las empresas españolas en sus Webs corporativas. Análisis de la información de responsabilidad social, ciudadanía corporativa y desarrollo sostenible. ZER—Revista de Estudios de Comunicación 2006, 11, 47-62.

122. Hamman, E.; Habisch, A.; Pechlaner, H. Values that create value: Socially responsible business practices in SME's-Empirical evidence from German companies. Bus. Ethics A Eur. Rev. 2009, 18, 37-51. [CrossRef]

123. Ayuso, S.; Garolera, J. Códigos éticos de las empresas españolas: ¿qué compromisos contienen? Revista de la Responsabilidad Social de la Empresa 2012, 11, 77-103.

124. Longo, M.; Mura, M.; Bonoli, A. Corporate social responsibility and corporate performance: The case of Italian SME's. Corp. Gov. 2005, 5, 28-42. [CrossRef]

125. Gálvez, M.A.; Caba, M.C.; López, M. Responsabilidad social y transparencia on line de las ONG: Análisis del caso español CIREC España. Revista de Economía Pública Social y Cooperativa 2012, 74, 207-238.

126. Camaran, M.L.; Baron, L.; Rueda, M.P. La responsabilidad social empresarial y los objetivos del desarrollo sostenible. TEACS. Revista Científica Teorías Enfoques y Aplicaciones en Las Ciencias Sociales 2018, 24, 41-52.

127. Berman, S.L.; Wicks, A.C.; Kotha, S.; Jones, T.M. Does stakeholder orientation matter? The relationship between stakeholder management models and firm financial performance. Acad. Manag. J. 1999, 42, 488-506.

128. López, M.V.; García, A.; Rodriguez, L. Sustainable development and corporate performance: A study based on the Dow Jones sustainability index. J. Bus. Ethics 2007, 75, 285-300. [CrossRef]

129. Gil, M.A.; Giner, F.; Griful, C. Benchmarking corporate social responsibility within Spanish companies. Int. Adv. Econ. Res. 2009, 15, 207-225.

130. Charlo, M.J.; Moya, I. El comportamiento financiero de las empresas socialmente responsables. Investigaciones Europeas de Dirección y Economía de la Empresa 2010, 16, 15-25. [CrossRef]

131. Godos-Diaz, J.L.; Fernandez-Gago, R.; Cabeza-García, L. Propiedad y control en la puesta en práctica de la RSC. Cuadernos de Economía y Dirección de Empresas 2012, 15, 1-11. [CrossRef]

132. Chin, W.W. How to write up and report PLS analyses. In Handbook of Partial Least Squares: Concepts, Methods and Applications; Esposito Vinzi, V., Chin, W.W., Henseler, J., Wang, H., Eds.; Springer: Berlin, Germany, 2010; pp. 655-690.

133. Hair, J.F.; Ringle, C.M.; Sarstedt, M. PLS-SEM: Indeed a silver bullet. J. Mark. Theory Pract. 2011, 19, 137-149. [CrossRef]

134. Jarvis, C.B.; Mackenzie, S.B.; Podsakoff, P.M. Acritical review of construct indicators and measurement model misspecification in marketing and consumer research. J. Consum. Res. 2003, 30, 199-218. [CrossRef]

135. Hair, J.F., Jr.; Hult, G.T.M.; Ringle, C.M.; Sarstedt, M.; Castillo Apraiz, J.; Cepeda Carrión, G.A.; Roldán, J.L. Manual de Partial Least Squares Structural Equation Modeling (PLS-SEM) (Segunda Edición); OmniaScience: Terrassa, Spain, 2019. [CrossRef]

136. Hair, J.F.; Risher, J.J.; Sarstedt, M.; Ringle, C.M. When to use and how to report the results of PLS-SEM. Eur. Bus. Rev. 2019, 31, 2-24. [CrossRef]

137. Rigdon, E.E.; Sarstedt, M.; Ringle, C.M. On Comparing Results from CB-SEM and PLS-SEM: Five Perspectives and Five Recommendations. Mark. ZFP 2017, 39, 4-16. [CrossRef]

138. Sarstedt, M.; Hair, J.F.; Ringle, C.M.; Thiele, K.O.; Gudergan, S.P. Estimation issues with PLS and CBSEM: Where the bias lies! J. Bus. Res. 2016, 69, 3998-4010. [CrossRef]

139. Chin, W.W.; Newsted, P.R. Structural equation modeling analysis with small samples using partial least squares. In Statistical Strategies for Small Samples Research; Hoyle, R., Ed.; Sage: Thousand Oaks, CA, USA, 1999; pp. 307-341.

140. Reinartz, W.; Haenlein, M.; Henseler, J. An empirical comparison of the efficacy of covariance-based and variance-based (SEM). Int. J. Res. Mark. 2009, 26, 332-344. [CrossRef]

141. Nitzl, C. The use of partial least squares structural equation modelling (PLS-SEM) in management accounting research: Directions for future theory development. J. Account. Lit. 2016, 37, 19-35. [CrossRef] 
142. Henseler, J.; Hubona, G.; Ray, P.A. Using PLS path modeling in new technology research: Updated guidelines. Ind. Manag. Data Syst. 2016, 116, 2-20. [CrossRef]

143. Hair, J.F., Jr.; Hult, G.T.M.; Ringle, C.; Sarstedt, M. A Primer on Partial Least Squares Structural Equation Modeling (PLS-SEM), 2nd ed.; Sage Publications: Thousand Oaks, CA, USA, 2017.

144. Hair, J.F., Jr.; Sarstedt, M.; Hopkins, L.; Kuppelwieser, V.G. Partial least squares structural equation modeling (PLS-SEM): An emerging tool in business research. Eur. Bus. Rev. 2014, 26, 106-121. [CrossRef]

145. Nunnally, J.C.; Bernstein, I.H. Psychometric Theory, 3rd ed.; McGraw-Hill: New York, NY, USA, 1994.

146. Dijkstra, T.K.; Henseler, J. Consistent Partial Least Squares Path Modeling. MIS Q. 2015, 39, $297-316$. [CrossRef]

147. Bagozzi, R.P. Structural equation models in marketing research: Basic principles. In Principles of Marketing Research; Bagozzi, R.P., Ed.; Blackwell: Oxford, UK, 1994; pp. 317-385.

148. Fornell, C.; Larcker, D.F. Evaluating structural equation models with unobservable variables and measurement error. JMR 1981, 18, 39-50.

149. Henseler, J.; Ringle, C.M.; Sinkovics, R.R. The use of partial least squares path modeling in international marketing. In New Challenges to International Marketing; Emerald Group Publishing Limited: Bingley, UK, 2009; pp. 277-319.

150. Fernández-Portillo, A.; Almodóvar-González, M.; Sánchez-Escobedo, M.C. Análisis del impacto de la innovación, las TIC y el clima empresarial sobre los ingresos de las PYMES. Revista Internacional de Organizaciones 2020, 24. In press.

151. Fernández-Portillo, A.; Almodóvar-González, M.; Coca-Pérez, J.L.; Jiménez-Naranjo, H.V. Is Sustainable Economic Development Possible Thanks to the Deployment of ICT? Sustainability 2019, 11, 6307. [CrossRef]

152. Diamantopoulos, A.; Siguaw, J.A. Formative Versus Reflective Indicators in Organizational Measure Development: A Comparison and Empirical Illustration. Br. J. Manag. 2006, 17, 263-282. [CrossRef]

153. Roberts, N.; Thatcher, J.B. Conceptualizing and testing formative constructs: Tutorial and annoted example. Data Base Adv. Inf. Syst. 2009, 40, 9-39. [CrossRef]

154. Sarstedt, M.; Ringle, C.M.; Hair, J.F. PLS-SEM: Looking Back and Moving Forward. Long Range Plan. 2014, 47, 132-137. [CrossRef]

155. Groß, M. Heterogeneity in consumers' mobile shopping acceptance: A finite mixture partial least squares modelling approach for exploring and characterising diferent shopper segments. J. Retail. Consum. Serv. 2018, 40, 8-18. [CrossRef]

156. Robina-Ramírez, R.; Fernández-Portillo, A.; Díaz-Casero, J.C. Green Start-Ups' Attitudes towards Nature When Complying with the Corporate Law. Complexity 2019, 2019, 4164853. [CrossRef]

157. Aragón-Correa, J.A.; Rubio-López, E.A. Proactive corporate environmental strategies: Myths and misunderstandings. Long Range Plan. 2007, 40, 357-381. [CrossRef]

158. Link, S.; Naveh, E. Standardization and discretion: Does the environmental standard ISO14001 lead to performance benefits? IEEE Trans. Eng. Manag. 2006, 53, 508-519. [CrossRef]

159. Goll, I.; Rasheed, A.A. The moderating effect of environmental munificence and dynamism on the relationship between discretionary social responsibility and firm performance. J. Bus. Ethics 2004, 49, 41-54. [CrossRef]

160. Cuevas, I.Y.; Rocha, L.; Soto, M.R. Certificación ambiental ISO 14000, como fuente de ventaja competitive y su impacto financiero. Red Internacional de Investigadores en Competitividad 2013, 1, 886-902.

(C) 2019 by the authors. Licensee MDPI, Basel, Switzerland. This article is an open access article distributed under the terms and conditions of the Creative Commons Attribution (CC BY) license (http://creativecommons.org/licenses/by/4.0/). 